\title{
ArcheoSciences
}

Revue d'archéométrie

33 (suppl.) | 2009

Mémoire du sol, espace des hommes

\section{Automatic magnetic mapping of the oppidum of Boviolles (Meuse, France)}

T. Dechezleprêtre, Michel Dabas and K. Gruel

\section{(2) OpenEdition}

1 Journals

Electronic version

URL: https://journals.openedition.org/archeosciences/1271

DOI: 10.4000/archeosciences. 1271

ISBN: 978-2-7535-1599-4

ISSN: $2104-3728$

Publisher

Presses universitaires de Rennes

Printed version

Date of publication: 30 October 2009

Number of pages: $51-53$

ISBN: 978-2-7535-0943-6

ISSN: 1960-1360

\section{Electronic reference}

T. Dechezleprêtre, Michel Dabas and K. Gruel, "Automatic magnetic mapping of the oppidum of

Boviolles (Meuse, France)", ArcheoSciences [Online], 33 (suppl.) | 2009, Online since 30 October 2011, connection on 21 September 2021. URL: http://journals.openedition.org/archeosciences/1271 ; DOI: https://doi.org/10.4000/archeosciences. 1271 


\title{
Automatic magnetic mapping of the oppidum of Boviolles (Meuse, France)
}

\author{
T. Dechezleprêtre*, M. Dabas** and K. Gruel *
}

Key words: Magnetic survey, Oppidum, Rural settlement, Aristocracy.

The oppidum of Boviolles is one of the most important Gallic fortifications included in the East of Gallia PCR (Collective Research Program): "Nasium, from oppidum to Gallo-Roman town" with the financial support of the Conseil general de la Meuse Council and French Ministry of Culture. The presence of both a Gallic fortification (main occupation between 2nd and 1st century BC) and a GalloRoman town makes this site important for understanding urbanisation processes (Dechezleprêtre et al., 2007; Dechezleprêtre, 2008).

The surface of the oppidum - more than 60 ha - required the use of several surveying techniques like field walking, geophysics and archaeological trenching. The magnetic survey was undertaken over 40 ha (spacing between profiles $50 \mathrm{~cm}$, acquisition frequency $50 \mathrm{~Hz}$ ). The surveys were done manually and the first trials of AMP (Automatic Magnetic Surveying using a quad-bike) were done with success in 2006 using sensors from Foerster interfaced with a dGPS and homemade GIS software (Geocarta SA). This system enabled the survey of more than 10 ha a day, whereas manual surveys give less than 1 ha per day (including topography).

The AMP system (Fig. 1) designed by GEOCARTA SA comprises a non-magnetic cart which can support up to five magnetic sensors, low-noise vertical fluxgate sensors specifically designed by Bartington for this application, an electronic system for acquisition and filtering the analog output signals of the sensors, a dGPS for the acquisition in real-time

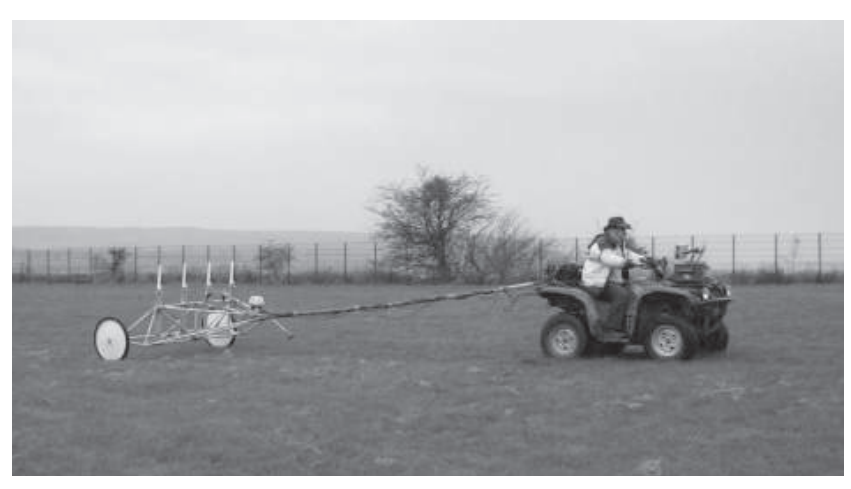

Figure 1: System AMP in action.

(no post-processing) of positioning data and finally of software for real-time acquisition of these data. The software is part of a homemade GIS already used for the acquisition of continuous electrical data (ARPC system). The acquisition rate along the profile is $80 \mathrm{~Hz}$. Considering an average speed of acquisition of $4 \mathrm{~m} / \mathrm{s}$, the sampling interval is $5 \mathrm{~cm}$ along the profiles. The distance between sensors is $50 \mathrm{~cm}$. Distance between profiles is $2.5 \mathrm{~m}$. The navigation is computer-aided: the operator has to follow lines which are drawn on the screen parallel to each other and spaced $2.5 \mathrm{~m}$ apart. At the same time, the output of the five sensors is displayed in realtime for quality check.

* CNRS/ENS, UMR AOROC CNRS/ENS-Paris, Conseil général Vosges. (tdechezlepretre@cg88.fr)

** GEOCARTA, Paris. (dabas@geocarta.net) 
Processing of the data is standard: synchronisation of magnetic and positioning data, removal of mean value over each profile and for each sensor, 1D removal of outliers and 2D gridding by spline function.

The geophysical maps prove that the entire surface was occupied and that specific high concentration areas exist (Fig. 2). The magnetic anomalies recorded represent different kinds: punctual, linear and diffuse. The most important is a linear anomaly which corresponds to a ditch running for $1200 \mathrm{~m}$, which does not actually divide the plateau, but rather isolates the highest part of the oppidum. Other anomalies can also be seen and correspond to small ditches which limit dwelling blocks oriented along the different pathways which cross this Gallic agglomeration. As for the punctual anomalies, they correspond to caves, excavated workshops, extraction and rejection pits and wells. Archaeological excavations have enabled the identification of diffuse anomalies. They correspond mainly to layers with a high concentration of archaeological artifacts (Fig. 3).

In conclusion, the use of geophysical maps has brought information not only about the internal structure of this site, but has also provided elements to understand the level of conservation of the remains.

\section{References}

Dechezleprêtre, T., Méniel, P. and Bonaventure, B., 2007. L'oppidum de Nasium à Boviolles (Meuse): état des recherches actuelles. In Barral, P., Daubigney, A., Dunning, C., Kaenel, G., Rouliere-Lambert, M.-J. (dir.). L'âge du Fer dans l'arc jurassien et ses marges. Dépôts, lieux sacrés et territorialité à l'âge du Fer. Actes du XXIX colloque international de l'Association Française de l'Age du Fer; Bienne 5-8 mai 2005, Besançon: Presses universitaires de Franche-Comté (Annales Littéraires), 45-54.

Dechezleprêtre, T., 2008. L'urbanisation de l'Est de la Gaule : quelques réflexions à partir des recherches récentes sur l'oppidum de Boviolles (Meuse). Le Pays Lorrain, 2008: 119-123.

This geophysical survey has been financed partly by the program ANR CELTECOPHYS.

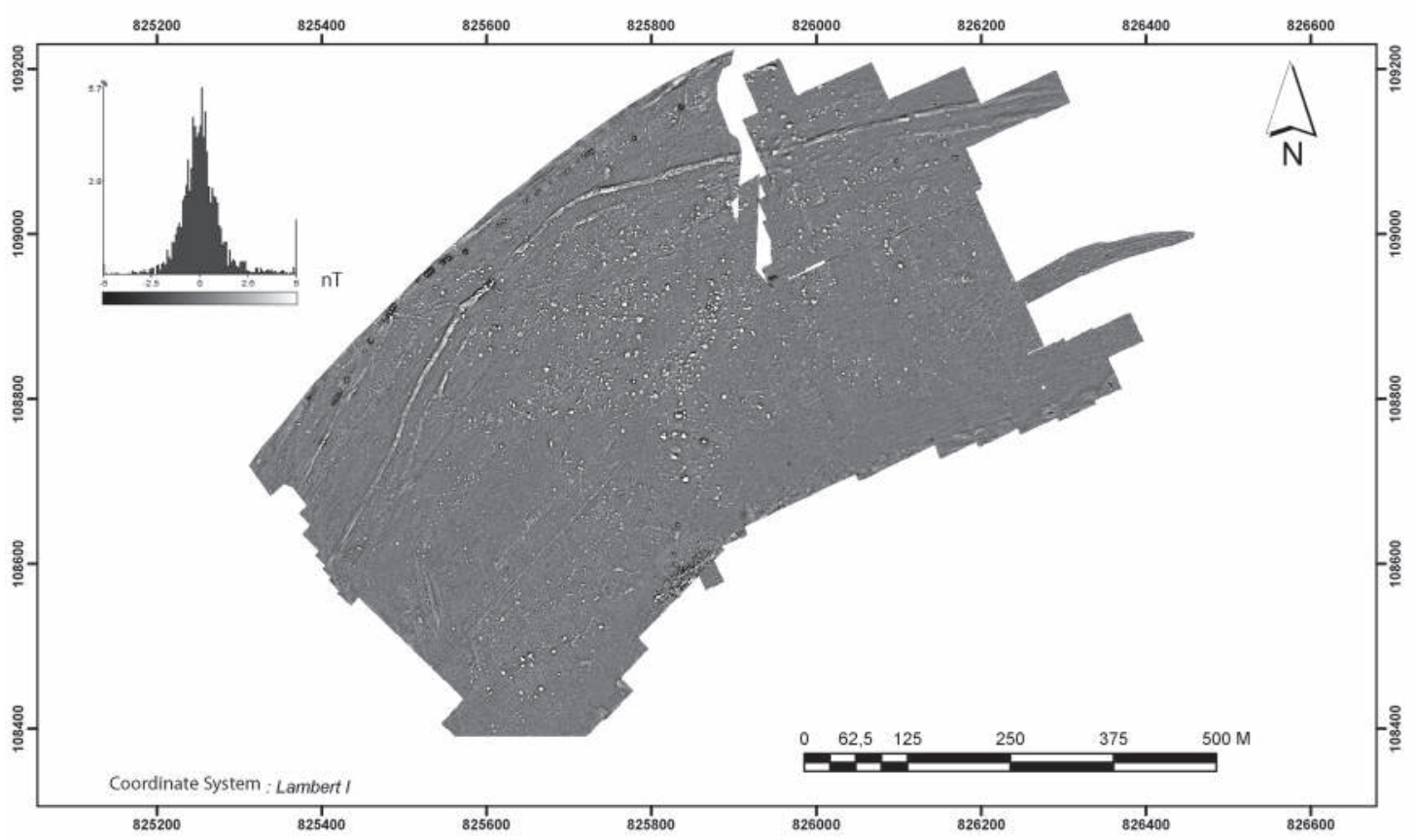

Figure 2: Magnetic survey of the site (Terra Nova 2007). 
Figure 3 (see color plate): Aerial photo superposed with interpretation.

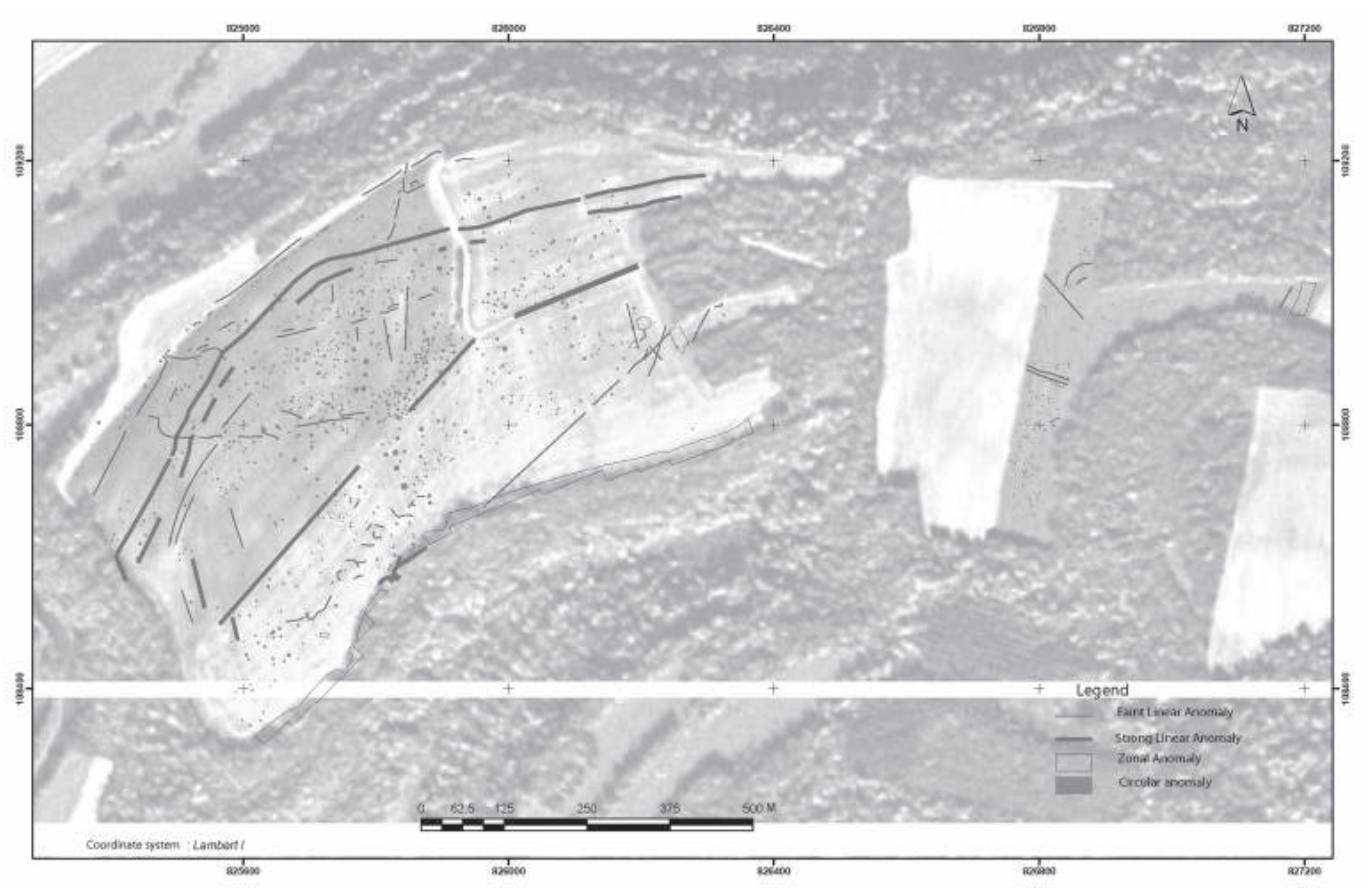

